\title{
ŻYCIE NAUKOWE INSTYTUTU HISTORII UNIWERSYTETU W BIAEYMSTOKU W LATACH 2008/2009
}

Życie naukowe Instytutu Historii UwB w roku akademickim 2008/2009 zainaugurowane zostało jeszcze przed rozpoczęciem zajęć dydaktycznych. W dniach 18-19 września 2008 r. odbyła się konferencja „Granice i pogranicza. Mikrohistorie", która połączona była z uroczystościami obchodów czterdziestolecia studiów historycznych w Białymstoku. Konferencji naukowej towarzyszyły spotkania wykładowców, absolwentów i obecnych studentów oraz promocja książki Studia historyczne w Białymstoku wspomnieniami opisane (1968-2008), wydanej z tej okazji przez Instytut Historii. Właściwy początek roku akademickiego na Wydziale Historyczno-Socjologicznym miał miejsce 2 października 2008 r. Wykład inauguracyjny nt. „Globalizacja a bieda" do studentów kierunków historia i stosunki międzynarodowe skierowała prof. Barbara Stępniewska-Holzer. Od 1 października 2008 r. funkcję dyrektora Instytutu Historii zaczął pełnić dr hab. Wojciech Śleszyński, prof. UwB.

Pierwszy miesiąc nowego roku akademickiego zaowocował kolejną konferencją z cyklu „Lata Wielkiej Wojny”. Kontynuując zagadnienie z wcześniejszego spotkania zatytułowanego „Dojrzewanie do niepodległości 1914-1918”, dyskutowano nad problemem „Rok 1918 w Europie Środkowo-Wschodniej”. Konferencja odbyła się 23 października 2008 r. Uczestnicy obradowali w sali audytoryjnej Biblioteki Głównej przy ulicy M. Skłodowskiej-Curie. Referaty wygłoszone podczas tego spotkania zostały przygotowane do publikacji w zbiorze noszącym tytuł konferencji.

W ramach cyklicznych spotkań „Kresy Rzeczypospolitej - obszary zgody czy konfliktów?", organizowanych przez Instytut wspólnie z Polskim To- 
warzystwem Historycznym Oddział w Białymstoku, 24 listopada 2008 r. odbył się wykład księdza prof. dra hab. Zygmunta Zielińskiego (KUL). Tematem wystąpienia prelegenta były „Kresy jako obszar ekspansji na przykładzie pogranicza polsko-niemieckiego". Natomiast 9 grudnia 2008 r. dr hab. Krzysztof Buchowski, prof. UwB, wygłosił referat na temat: „Polacy i Litwini - wzajemne postrzeganie przez wieki”, w ramach cyklu „Podlaskie w badaniach naukowych", w Bibliotece Uniwersyteckiej im. J. Giedroycia.

Przełom lat 2008/2009 przyniósł kolejne tytuły profesorskie. Prezydent RP przyznał tytuł naukowy profesora nauk humanistycznych: prof. dr hab. Teresie Chynczewskiej-Hennel, prof. dr hab. Halinie Parafianowicz i prof. drowi hab. Eugeniuszowi Mironowiczowi. Natomiast Małgorzata Dajnowicz otrzymała tytuł doktora habilitowanego.

Wiosna 2009 r. okazała się okresem intensywnych kontaktów naukowych w ramach konferencji organizowanych przez pracowników Instytutu Historii. 23-25 kwietnia w Białowieży odbyła się konferencja „Wobec króla i Rzeczypospolitej. Magnateria w XV-XVIII wieku". Została ona zorganizowana już po raz czwarty przez Zakład Historii Nowożytnej w ramach serii poświęconej problematyce magnackiej. Efekty dotychczasowych obrad zostały opublikowane $\mathrm{w}$ dwóch książkach. W tegorocznych dyskusjach poruszono kwestie związane z polityczną i militarną rolą magnaterii jako elity działającej w orbicie władzy lub pozostającej w opozycji wobec niej, aktywnej zarówno w wymiarze państwa, jak i w skali lokalnej.

Pracownicy Zakładu Historii Średniowiecza i NPH do końca XVIII w. przygotowali konferencję poświęconą „Rynkom lokalnym i regionalnym od XIV do XVIII wieku", która odbyła się w Instytucie Historii w Białymstoku w dniach 25-26 maja 2009 r. Zaproszone zostały różne ośrodki badawcze. Wśród referentów nie zabrakło również gości z zagranicy. Większość referentów prezentowała obserwacje dotyczące ekonomii rynku na przestrzeni wieków, jakie miała okazję poczynić na marginesie badań jedynie pośrednio związanych z życiem gospodarczym. Swoją obecnością zaszczycił gospodarzy i gości dr hab. Marian Dygo, prof. UW - mediewista, badacz dziejów gospodarczych, znawca historii średniowiecza zachodniej Europy. Ponadto dzięki konferencji udało się nawiązać obiecujące kontakty z badaczami historii gospodarki z Ukrainy.

Dzięki współpracy Oddziału IPN w Białymstoku, Ośrodka Badań Naukowych im. W. Kętrzyńskiego w Olsztynie oraz Instytutu Historii UwB, 4-5 czerwca 2009 r. odbyła się konferencja „Społeczeństwo Polski północno-wschodniej wobec przemian ustrojowych w latach 1989-2009". Spotkaniu wokół wspomnianego tematu towarzyszyła wystawa druków okolicznościo- 
wych związanych z wyborami w czerwcu 1989 r., przygotowana przez Książnicę Podlaską i OBEP w Białymstoku.

1 czerwca 2009 r. Instytut Historii gościł Egidijusa Meilunasa - ambasadora Republiki Litewskiej w Polsce, z wykładem „Litwa - Polska: od Unii do Unii". Podczas spotkania, w którym uczestniczył rektor UwB, prof. dr hab. Jerzy Nikitorowicz oraz dyrektor Instytutu Historii UwB, dr hab. Wojciech Śleszyński, prof. UwB, poruszony został problem współpracy polsko-litewskiej w przeszłości i obecnie. Dyskutowano na temat możliwości i szans na pogłębienie relacji Polski i Litwy, zwłaszcza w zakresie edukacji, na przykład poprzez aktywizację studiów lituanistycznych.

Ważnymi wydarzeniami w życiu naukowym Instytutu były kolejne publiczne obrony prac doktorskich. Od momentu uzyskania przez Instytut Historii (1993) prawa nadawania stopnia naukowego doktora nauk humanistycznych w zakresie historii, nadano go 45 osobom (stan na 1 października 2009 r.). Należy podkreślić, że zdecydowaną większość autorów doktoratów stanowili absolwenci Instytut Historii, a ich promotorami byli przede wszystkim pracownicy Instytutu, co wskazuje na dużą aktywność badawczą prowadzonych w Białymstoku seminariów doktorskich oraz osiągnięcie przez białostockie środowisko historyczne dojrzałości naukowej. W latach 2008-2009 w Instytucie Historii znaczna liczba doktorantów uzyskała stopień: 15 maja 2008 r. - Urszula Kraśnicka-Zajdler, Biskup - tułacz abp. Józef Feliks Gawlina (1892-1964) (promotor - dr hab. Krzysztof Filipow, prof. UwB); 19 czerwca 2008 r. - Andrzej Smolarczyk, Szkolnictwo powszechne i oświata w województwie poleskim w latach 1919-1939 (promotor - prof. dr hab. Zofia Tomczonek); Sylwia Kuźma-Markowska, Ruch kontroli urodzeń w Stanach Zjednoczonych na przyktadzie stanu Illinois (1923-1941) (promotor prof. dr hab. Halina Parafianowicz); 18 grudnia 2008 r. - Andrei Zamoiski, Transformation of small towns (shtetls) of Soviet Belarus' (1921-1932) (Transformacja miasteczek Sowieckiej Białorusi w latach 1921-1932) (promotor - dr hab. Daniel Grinberg, prof. UwB) oraz 25 czerwca 2009 r. Krzysztof Flis, Polityka Stanów Zjednoczonych wobec Wietnamu w latach prezydentury Dwighta Eisenhowera (1953-1956) (promotor - prof. dr hab. Halina Parafianowicz). Rada Naukowa Instytutu dokonała także wszczęcia nowych przewodów doktorskich: Jackowi Jaworskiemu, Polskie formacje wojskowe na obczyźnie w XVIII-XIX w. (promotor - dr hab. Krzysztof Filipow, prof. UwB); Krzysztofowi Jodczykowi, Krajobraz kulturowy powiatu brastawskiego w 1784 r. i jego uwarunkowania historyczne (promotor dr hab. Józef Maroszek, prof. UwB); Piotrowi Łapińskiemu, Wojskowy Sad Rejonowy w Biatymstoku w latach 1946-1955 (promotor - dr hab. Adam 
Dobroński, prof. UwB); Marcie Piszczatowskiej, Miasto Knyszyn i starostwo knyszyńskie w latach 1572-1663 (promotor - dr hab. Józef Maroszek); Izabeli Szymańskiej, Hrabstwo Zabłudowskie od 1599 roku do końca XIX w. Krąg dzierżawców, administratorów i urzędników (promotor - dr hab. Józef Maroszek, prof. UwB); Emilii Świętochowskiej-Bobowik, Polityka wtadz państwowych $i$ partyjnych wobec nauczycieli w województwie białostockim w latach 1944-1956, (promotor - dr hab. Hanna Konopka, prof. UwB); Katarzynie Wiszowatej-Walczak, Piotr Vidoni - nuncjusz w Rzeczypospolitej 1652-1660 (promotor - prof. dr hab. Teresa Chynczewska-Hennel).

Instytut Historii uczestniczy w międzynarodowym programie SOKRATES-ERASMUS. Studiując historię w naszym Instytucie, studenci mają możliwość odbycia części studiów na jednym z uniwersytetów europejskich: University of Craiova (Rumunia), Vilniaus Universitas (Wilno - Litwa), University of Latvia (Ryga - Łotwa), University of Joensuu (Finlandia), University of Hradec Kralove (Czechy), Freie Universitaet Berlin (Niemcy), Sakarya University (Turcja), Yeditepe University (Turcja), Kocaeli University (Turcja), Universita degli Studi di Verona (Włochy), Universita degli Studi della Tuscia (Viterbo - Włochy), Centre d'Etudes Europeennes (Francja), National \& Kapodistrian University of Athens (Grecja). Sam wyjazd nie tylko jest okazją do studiowania w ciekawym miejscu, daje także możliwość poznania innych zwyczajów - nie tylko akademickich - ludzi, doszlifowania znajomości języka obcego lub poznania zupełnie nowego - np. greki, tureckiego, włoskiego czy litewskiego. W ramach programu LLP ERASMUS Jaroslav Danesa PhD z Univerzita Hradec Kralove wygłosił w Instytucie Historii UwB dwa wykłady: „Some remarks about the problem of heredity in ancient Greek philosophy and medicine” i „Criltical discussion about the concept of human nature in Hippocratic writings". Instytut Historii współpracuje z wieloma ośrodkami naukowymi poza granicami kraju. W ramach Teching Staff Mobility pracownicy Instytutu Historii wyjeżdżają do europejskich ośrodków naukowych.

Ważnym elementem życia naukowego uczelni jest działalność studencka. Aktualnie w ramach Studenckiego Koła Naukowego Historyków działa dziewięć sekcji. Jedna z nich, Sekcja Historii Najnowszej, jest tworzona zarówno przez studentów historii, jak i stosunków międzynarodowych. Istotnym przedsięwzięciem tej sekcji było zaproszenie dra hab. Antoniego Dudka, prof. UJ - pracownika naukowego Instytutu Nauk Politycznych i Stosunków Międzynarodowych Uniwersytetu Jagiellońskiego i Instytutu Pamięci Narodowej oraz prof. dra hab. Andrzeja Friszke, byłego członka Kolegium Instytutu Pamięci Narodowej. Debatę „Okrągły Stół. Między mitem a rze- 
czywistością" z ich udziałem poprowadził w auli Wydziału Historyczno-Socjologicznego 23 kwietnia 2009 r. prof. dr hab. Jan Kofman.

Istotny efekt działalności naukowej pracowników Instytutu Historii stanowia publikacje. We wspomnianym okresie ukazały się m.in.: Przemyst cukrowniczy w Królestwie Polskim Jana Godlewskiego, Chłopi i pieniadze na przełomie średniowiecza i czasów nowożytnych Piotra Guzowskiego, Demografia Rzeczypospolitej przedrozbiorowej Cezarego Kukli, Zarys dziejów prawostawia w Europie Środkowo-Wschodniej, Diecezja białoruska w XVII i XVIII w., Monaster Wniebowstapienia Pańskiego w Puszczy Błudowskiej, Summariusz dokumentów do dóbr supraskich prof. Antoniego Mironowicza, Wyścig pokoju w dokumentach władz partyjnych i państwowych 1948-1989 Artura Pasko, Finat epopei Legionów Polskich 1916-1918 Jana Snopko, Świat pogranicza. Stosunki społeczno-polityczne na pograniczu polsko-litewsko-biatoruskim w XX i XXI wieku Wojciecha Śleszyńskiego. Wiele instytutowych publikacji stanowia prace redakcyjne, takie jak Dziedzictwo komunizmu w Europie Środkowo-Wschodniej pod redakcją Joanny Sadowskiej, czy Polesie w polityce rzadów II Rzeczypospolitej Polski, opracowane przez Wojciecha Śleszyńskiego. Z okazji drugiej rocznicy śmierci dra hab. Henryka Rucińskiego wydano studia Res gestie Meridionales et Orientales pod redakcją Elżbiety Bagińskiej, poświęcone jego pamięci.

Instytut Historii wydaje dwa czasopisma o charakterze naukowym: „Studia Podlaskie” (dotychczas ukazało się siedemnaście tomów), „Białostockie Teki Historyczne" (wydano sześć tomów). W grudniu 2008 r. ukazał się dwudziesty ósmy (już!) numer „Białostockiego Magazynu «Gryfita»”, który został poświęcony dziejom edukacji. W najnowszym zeszycie można odnaleźć teksty pracowników i studentów Instytutu Historii. Autorzy artykułów zebranych w omawianym numerze zdecydowali się pokazać czytelnikom efekty osobistych doświadczeń związanych z historią edukacji, z własnymi poszukiwaniami i obserwacjami naukowymi czy pracą dydaktyczną.

W omawianym okresie wszyscy pracownicy Instytutu Historii z dużym zaangażowaniem reprezentowali placówkę na zewnątrz, poprzez uczestnictwo w licznych konferencjach krajowych i zagranicznych, zjazdach, panelach dyskusyjnych, nawiązując różne kontakty naukowe. Ogromny wkład pracy, a także widoczne osiągnięcia kadry Instytutu Historii stanowią doskonałą podstawę do tworzenia studiów trzeciego stopnia. Dlatego też dyrekcja Instytutu Historii w porozumieniu z dyrekcją Instytutu Socjologii podjęła starania o uprawnienia niezbędne do uruchomienia studiów doktoranckich. Wydział Historyczno-Socjologiczny 5 sierpnia 2009 r. otrzymał pozytywną odpowiedź Ministerstwa Nauki i Szkolnictwa Wyższego. Perspektywa utwo- 
rzenia studiów trzeciego stopnia stanowi ogromne wyzwanie dla pracowników i dyrekcji Instytutu, jednocześnie pozwala z nadzieją patrzeć w przyszłość jednostki stwarzającej możliwość kształcenia w ramach pełnego trzystopniowego systemu studiów wyższych.

Monika Szpakowska 